\title{
GENERALISASI ALGORITMA THINNING PROCESS PADA PROSES POISSON MAJEMUK DENGAN KOMPONEN PROSES POISSON NONHOMOGEN DAN DISTRIBUSI GAMMA
}

\author{
Syarif Abdullah*1, Sidik Susilo², Miftahul Huda ${ }^{3}$, Nina Valentika ${ }^{4}$, Sri \\ Istiyarti Uswatun Chasanah ${ }^{5}$, Agusyarif Rezka Nuha ${ }^{6}$, Aswata Wisnuadji ${ }^{7}$, \\ Fajri Ikhsan $^{8}$, Yazid Rukmayadi ${ }^{9}$ \\ 1,2,7,9 Department of Mechanical Engineering, Universitas Sultan Ageng Tirtayasa, \\ Banten, Indonesia \\ ${ }^{3}$ Department of Statistics, Universitas Bina Bangsa, Banten, Indonesia \\ ${ }^{4}$ Department of Mathematics, Universitas Pamulang, Banten, Indonesia \\ ${ }^{5}$ Department of Mathematics, Universitas Islam Negeri Sunan Kalijaga, \\ Yogyakarta, Indonesia \\ ${ }^{6}$ Department of Mathematics, Universitas Negeri Gorontalo, Gorontalo, Indonesia \\ ${ }^{8}$ Department of Metallurgy Engineering, Universitas Sultan Ageng Tirtayasa, \\ Banten, Indonesia \\ abdullahsyarifayis@untirta.ac.id*1, sidik@untirta.ac.id², \\ miftahulhuda.osima@gmail.com ${ }^{3}$,dosen02339@unpam.ac.id ${ }^{4}$, sri.chasanah@uin- \\ suka.ac.id ${ }^{5}$, agusyarif@ung.ac.id ${ }^{6}$, aswata_wisnuadji@untirta.ac.id ${ }^{7}$, \\ fajri.ikhsan@untirta.ac.id ${ }^{8}$, yazid.rukmayadi86@gmail.com ${ }^{9}$ \\ *Corresponding Author
}

Received 22 November 2020; revised 25 December 2020; accepted 27 December 2020.

\begin{abstract}
ABSTRAK
Proses Poisson majemuk (compound Poissonprocess (CPP)) adalah salah satu pengembangan dari teori stokastik yang digunakan untuk memodelkan fenomena nyata. Proses ini minimal memiliki dua komponen, yaitu komponen pada proses Poisson-nya berupa fungsi intensitas konstan atau fungsi tertentu dan komponen besaran akibat berupa distribusi tertentu. Penelitian ini bertujuan untuk membuat model CPP yang memiliki komponen fungsi intensitas nonhomogen pada proses Poisson-nya (non-homogeneous Poisson process (NHPP)) dan komponen besaran akibat yang berdistribusi gamma (gamma distribution (GD)). Selanjutnya dibuat penduga parameter (parameter estimation) dan algoritma membangkitkan CPP-NHPP-GD. Metode yang digunakan dalam menentukan penduga parameter yaitu metode moment. Sedangkan pembuatan algoritma pada penelitian ini menggunakan metode acceptance and rejections berupa generalisasi teknik thinning process. Hasil penelitian telah didapatkan rumusan penduga-penduga untuk fungsi nilai harapan dan varian pada CPP dengan komponen NHPP dan komponen GD. Penelitian ini didapatkan pula generalisasi algoritma thinning process pada CPP-NHPP-GD tipe 1
\end{abstract}




\title{
Syarif Abdullah, Sidik Susilo, Miftahul Huda, Nina Valentika, Sri Istiyarti Uswatun Chasanah, Agusyarif Rezka Nuha, Aswata Wisnuadji, Fajri Ikhsan, Yazid Rukmayadi
}

dan 2. Algoritma tipe 1 merupakan hasil modifikasi dan generalisasi algoritma dari model CPPHPP dengan mengubah komponen pada proses Poisson-nya menjadi bentuk NHPP dan komponen pada bagian besaran akibat berupa distribusi gamma. Algoritma tipe 2 merupakan hasil modifikasi dari tipe 1 dengan melakukan breakdown interval menjadi subinterval.

Kata kunci: distribusi gamma, generalisasi algoritma, penduga parameter, proses Poisson majemuk, proses Poisson nonhomogen.

\begin{abstract}
Compound Poisson process (CPP) is one of the developments of the stochastic theory used to model real phenomena. This process has at least two main components, that are the components in the Poisson process in the form of a constant intensity function or a certain function and the resulting magnitude component in the form of a certain distribution. This study aims to create a CPP model that has a non-homogeneous intensity function component in the Poisson process (NHPP) and a component of the resulting magnitude with a gamma distribution (GD). Furthermore, parameter estimation and algorithms are built to generate CPP-NHPP-GD. The method used in determining the parameter estimator is the moment method. Meanwhile, the algorithm in this study uses the acceptance and rejections method in the form of a generalization of the thinning process technique. The results of this research have obtained estimator formulations for the expected value and variance functions on the CPP with NHPP and GDcomponents. This reserch also obtained a generalization of the thinning process algorithm on CPP-NHPP-GD types 1 and 2. The type 1 algorithm is the result of modification and generalization of the algorithm from the CPP-HPP model by changing the components in the Poisson process into NHPP form and the component in the resulting part of the gamma distribution. Algorithm type 2 is a modification result from type 1 by doing a breakdown interval to subinterval.
\end{abstract}

Keywords: algorithm generalization, compound Poisson process, gamma distribution, nonhomogeneous Poisson process, parameter estimator.

\section{PENDAHULUAN}

Fenomena nyata pada kehidupan sehari-hari seringkali terdapat peristiwaperistiwa yang mengandung usur ketidakpastian, misalkan terjadinya gempa, banjir, fluktuasi suku bunga atau bahkan kematian. Dari peristiwa yang tidak pasti tersebut maka muncullah kejadian acak (random event), sehingga diperlukan ilmu untuk memprediksi kejadian yang terjadi secara acak (random event that 
occured). Langkah selanjutnya yang dilakukan adalah dengan membuat model yang sesuai atau yang meyerupai fenomena nyata yang dikaji.

Proses stokastik adalah suatu cabang ilmu yang mempelajari tentang suatu proses kejadian yang memiliki unsur ketidakpastian. Ditinjau dari segi proses waktu kejadian, proses ini secara garis besar dibagi menjadi dua, yaitu proses kejadian waktu diskret dan kontinu. Salah satu cabang dari proses stokastik dengan proses kejadian kontinu adalah proses Poisson. Proses Poisson adalah suatu proses pencacahan yang memiliki laju (fungsi intensitas) tertentu yang memiliki inkremen bebas dan banyaknya kejadian pada sebarang selang waktu panjang tertentu memiliki sebaran (distribusi) Poisson dengan nilai harapan tertentu pula, atau dalam arti memiliki inkremen stasioner. Proses Poisson secara garis besar terbagi menjadi dua pula, yaitu homogeneous Poisson process (HPP) dan nonhomogeneous Poisson process (NHPP). HPP adalah suau proses Poisson dengan laju tertentu yang memiliki fungsi konstan untuk setiap waktu. Sedangkan NHPP adalah sutu proses Poisson dengan laju tertentu yang memiliki fungsi tak konstan untuk sebarang waktu. Proses HPP memiliki arti bahwa kejadian ini tidak bergantung pada waktu, sedangkan proses NHPP memiliki arti bahwa kejadian ini bergantung pada waktu. Proses Poisson memiliki banyak aplikasi, misalnya pada bidang teknik yaitu maintenance planning: minimal repair (Beichelt, 2006), fibrous materials (Sampson, 2009), failure model (Cha, 2013), alat deteksi nuklir (Pahlajani et al., 2014), maintenance modelling (Andrzejczak et al., 2018), reliability model in engineering for automotive productions line (Soltanali et al., 2019) dan lain-lain.

Salah satu pengembangan dari proses stokastik selanjutnya adalah proses Poisson majemuk (compound Poisson process (CPP)). CPP minimal memiliki dua komponen utama, yaitu suatu komponen pada proses Poisson berupa fungsi intensitas konstan atau fungsi tertentu dan suatu komponen besaran akibat berupa distribusi tertentu. Pada proses ini mengandung arti bahwa pada proses stokastik yang didapatkan tidak hanya melihat berapa banyak kejadian itu terjadi atau muncul, namun juga diperhatikan besaran akibat atau efek dari kejadian tersebut bila terjadi atau muncul. Pada proses terjadinya suatu kejadian pada proses stokastik ini diasumsikan memiliki kejadian berupa proses Poisson, baik berupa 
Syarif Abdullah, Sidik Susilo, Miftahul Huda, Nina Valentika, Sri Istiyarti Uswatun Chasanah, Agusyarif Rezka Nuha, Aswata Wisnuadji, Fajri Ikhsan, Yazid Rukmayadi

HPP (memiliki intensitas konstan) atau NHPP (memiliki intensitas fungsi tak konstan). Sedangkan besaran akibat dari kejadian tersebut dapat diasumsikan memiliki distribusi tertentu, misalkan mengikuti sebaran (distribusi) seragam, eksponensial, gamma, Paretto atau yang lain, yang sesuai dengan fenomena.

Salah satu aplikasi proses Poisson majemuk yang memiliki proses kejadian berupa proses Poisson homogen (compound Poisson process-homogeneous Poisson process (CPP-HPP)) yaitu terdapat pada bidang asuransi dan keuangan, demografi, seismografi, biologi, dan bidang teknik (Abdullah et al., 2020a). Masalah yang terjadi dari model-model sebelumnya telah diasumsikan bahwa suatu kejadian memiliki kejadian yang konstan, sedangkan pada realitanya (dalam fenomena nyata) suatu kejadian tidaklah selalu konstan atau sering berubah seiring dengan waktu, sehingga perlu dikembangkan model baru yang sesuai. Proses Poisson majemuk yang memiliki proses kejadian berupa proses Poisson nonhomogen (compound Poisson process-nonhomogeneous Poisson process (CPP-NHPP)) belum banyak dikaji, sehingga peneliti fokus pada penelitian tersebut. CPP-NHPP yang memiliki fungsi intensitas berupa fungsi periodik telah diteliti pada Mangku et al. (2013), Ruhiyat et al. (2013) dan Makhmudah et al. (2016). Sedangkan untuk fungsi periodik yang memilki tren linear telah diteliti pada Wibowo et al. (2017) dan Abdullah et al. (2017). Namun pada penelitian di atas belum dibahas pada bagian komponen akibat yang berdistribusi tertentu. Penelitian Abdullah et al. (2020a) telah dibahas proses Poisson majemuk yang memiliki komponen pada proses kejadian berupa proses Poisson nonhomogen (compound Poisson process-nonhomogeneous Poisson process (CPP-NHPP)) dan komponen pada bagian besaran akibat berupa distribusi eksponensial (exponential distribution (ED).

Metode yang sering digunakan untuk membangkitan proses Poisson (baik berupa HPP atau NHPP) yaitu dengan metode acceptance and rejection berupa teknik thinning process. Oleh karena itu, untuk membangkitkan CPP-HPP dan CPP-NHPP berupa teknik thinning process diperlukan modifikasi dan generalisasi. Pada penelitian Abdullah et al. (2019) telah dibahas modifikasi algoritma CPP-HPP dan CPP-NHPP, namun belum pada bentuk komponen pada bagian akibat berupa distribusi tertentu. Pada penelitian Abdullah et al. (2020a) 
telah dibahas modifikasi algoritma CPP-HPP dan CPP-NHPP pada bentuk komponen pada bagian akibat berupa distribusi eksponensial (CPP-NHPP-ED). Sedangkan pada penelitian Abdullah et al. (2020b) telah dikaji CPP-NHPP-ED berupa fungsi linear pada komponen proses Poison-nya.

Distribusi gamma adalah keluarga dari distribusi probabilitas kontinu yang memiliki dua parameter utama, yaitu parameter bentuk (shape) dan parameter skala (scale). Kasus khusus dari distribusi gamma yaitu distribusi eksponensial, distribusi Erlang dan distribusi chi-squared. Distribusi ini memiliki banyak aplikasi, misalnya pada ekonometri, keuangan dan asuransi. Sehingga pada penelitian ini peneliti bertujuan untuk membuat model compound Poisson process (CPP) yang memiliki komponen fungsi intensitas nonhomogen pada proses Poisson-nya (non-homogeneous Poisson process (NHPP)) dan komponen akibat yang berdistribusi gamma (gamma distribution (GD)) (CPP-NHPP-GD). Selanjutnya dibuat penduga parameter (parameter estimator) dan generalisasi algoritma untuk membangkitkan CPP-NHPP-GD.

Hasil pembuatan model, penduga parameter dan algoritma yang dihasilkan merupakan hasil pengembangan teoritis dan analisis simulasi komputasi yang dapat diterapkan di berbagai bidang ilmu. Dalam bidang teknik, model ini dapat digunakan sebagai analisis reabilitas, sedangkan pada bidang asuransi dan keuangan model ini dapat digunakan dalam teori risiko, khususnya pada ukuran risiko. Dengan memperhatikan reabilitas dan risiko, maka perusahaan diharapkan dapat merencanakan langkah ke depan sehingga tidak terjadi kerugian dan kebangkrutan.

\section{METODE PENELITIAN}

Keterbatasan pada model proses Poisson majemuk yang diasumsikan pada komponen terjadinya suatu kejadian berupa proses Poisson homogen, yang mana memiliki fungsi intensitas konstan, maka model tersebut perlu dilakukan pengembangan teori lebih lanjut agar dapat mencerminkan fenomena riil. Langkah awal dalam pembuatan model tersebut yaitu dengan mengubah definisi model CPP-HPP menjadi CPP-NHPP. Sedangkan pada komponen akibat dapat dikembangkan dengan memilih keluarga dari variabel acak i.i.d (independent and 
Syarif Abdullah, Sidik Susilo, Miftahul Huda, Nina Valentika, Sri Istiyarti Uswatun Chasanah, Agusyarif Rezka Nuha, Aswata Wisnuadji, Fajri Ikhsan, Yazid Rukmayadi

identically distributed) yang bebas dari proses pencacahan NHPP. Langkah selanjutnya yaitu menghitung nilai harapan dan varian pada proses Poisson majemuk tersebut. Karena proses Poisson majemuk ini bergantung pada waktu, maka nilai harapan dan varian ini berupa fungsi, yang berturut-turut disebut sebagai fungsi nilai harapan dan fungsi varian.

Karena untuk mengetahui sebaran dari proses Poisson majemuk ini sangat sukar untuk dicari atau ditemukan, maka dilakukan penduga proses Poisson majemuk ini. Langkah awal dalam menduga proses Poisson majemuk ini yaitu dengan melakukan penduga pada fungsi nilai harapan dan varian. Pada penduga fungsi nilai harapan ini terdapat perkalian antara penduga nilai harapan proses Poisson dan penduga nilai harapan dari komponen akibat. Dalam penduga nilai harapan proses Poisson harus dicari terlebih dahulu penduga parameternya, begitu pula untuk penduga nilai harapan dari komponen akibat. Sedangkan pada penduga fungsi varian ini juga terdapat perkalian antara penduga nilai harapan proses Poisson dan penduga nilai harapan dari komponen akibat yang dikuadratkan. Dalam penduga nilai harapan proses Poisson harus dicari terlebih dahulu penduga parameternya, begitu pula untuk penduga nilai harapan dari komponen akibat yang dikuadratkan. Pada penelitian ini disajikan rumusan penduga pada komponen proses Poisson berupa proses Poisson nonhomogen dan komponen pada bagian akibat menggunakan metode moment.

Setelah dirumuskan penduga-penduga yang telah dibahas di atas, maka disusunlah algoritma dalam membangkitkan proses Poisson majemuk yang memiliki komponen proses Poisson nonhomogen dan komponen akibat. Pada komponen akibat pada penelitian ini yaitu berupa distribusi gamma. Metode yang digunakan dalam penyusunan program ini dengan menggunakan metode simulasi komputasi acceptance and rejection dengan teknik thinning process. Teknik ini pertama kali diperkenalkan pada Lewis dan Shelder (1979) dan selanjutnya dikembangkan dan dimodifikasi pada Ross (2012). Generalisasi algoritma pada penelitian ini adalah hasil dari modifikasi dan generalisasi dari Abdullah (2019, 2020a, 2020b). Adapun langkah-langkah atau alur yang dilakukan dalam penelitian ini diilustrasikan pada Gambar 1. 


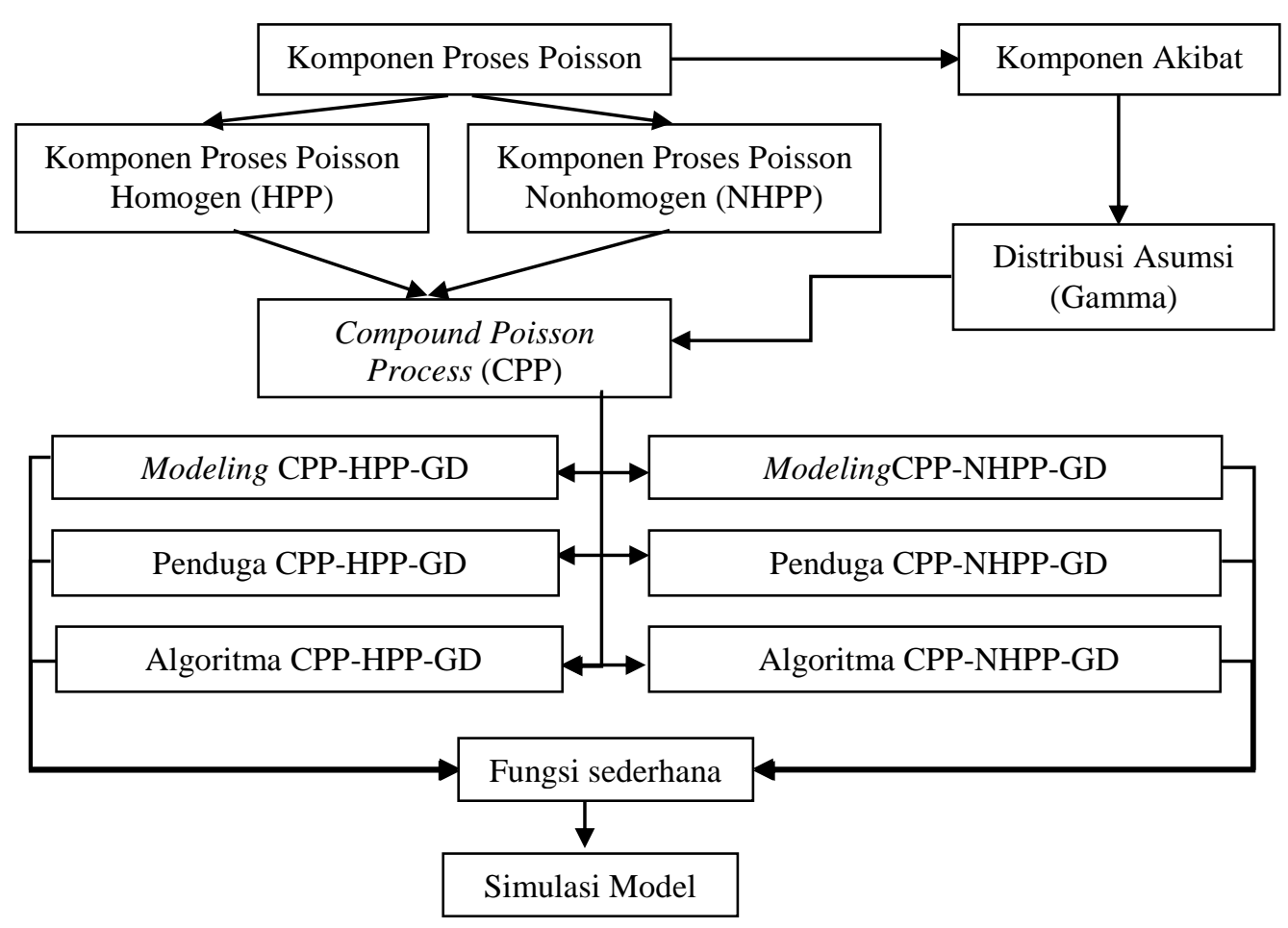

Gambar 1. Alur Penelitian

\section{HASIL PENELITIAN DAN PEMBAHASAN}

Berikut disajikan pembahasan dari hasil penelitian yang telah dicapai, yaitu CPP-HPP-GD, CPP-NHPP-GD, penduga parameter pada CPP-NHPP-GD. Sedangkan pada akhir pembahasan disajikan generalisasi algoritma CPP-NHPPGD.

\section{CPP-HPP-GD}

Banyaknya kejadian yang terjadi pada waktu T dapat direpresentasikan oleh proses pencacahan $\{\mathrm{N}(\mathrm{t}), \mathrm{t} \geq 0\}$. Jika proses ini berdistribusi Poisson dengan fungsi intensitas $\lambda>0$, maka proses ini dikatakan sebagai proses Poisson homogen (homogeneous Poisson process (HPP)). Karena memiliki fungsi intensitas yang konstan, maka proses ini dikatakan tidak bergantung pada waktu. Hal ini dikarenakan setiap waktu yang diambil maka selalu menghasilkan nilai yang sama. Definisi, nilai harapan, varian dan beberapa teorema terkait HPP dapat dilihat pada Ross (2019).

$$
\mathrm{E}[\mathrm{N}(\mathrm{t})]=\lambda \mathrm{t} \text { dan } \operatorname{var}[\mathrm{N}(\mathrm{t})]=\lambda \mathrm{t} .
$$


Syarif Abdullah, Sidik Susilo, Miftahul Huda, Nina Valentika, Sri Istiyarti Uswatun Chasanah, Agusyarif Rezka Nuha, Aswata Wisnuadji, Fajri Ikhsan, Yazid Rukmayadi

Definisi compound Poisson process-homogeneous Poisson process (CPPHPP) adalah sebagai berikut:

Definisi 1. Suatu proses $\{\mathrm{Y}(\mathrm{t}), \mathrm{t} \geq 0\}$ dikatakan sebagai suatu proses Poisson majemuk, jika proses tersebut dapat direpresentasikan sebagai,

$$
Y(t)=\sum_{i=1}^{N(t)} X_{i}, t \geq 0
$$

dengan $\{\mathrm{N}(\mathrm{t}), \mathrm{t} \geq 0\}$ adalah suatu proses Poisson dan $\left\{\mathrm{X}_{\mathrm{i}}, \mathrm{i} \geq 1\right\}$ adalah suatu keluarga dari variabel acak yang i.i.d. (independent and identically distributed) yang juga bebas dari proses $\{\mathrm{N}(\mathrm{t}), \mathrm{t} \geq 0\}$ (Ross, 2019).

CPP memiliki dua komponen utama, yaitu komponen banyaknya kejadian, yang biasa disebut komponen frekuensi, dimana diasumsikan berupa proses Poisson dan komponen besaran akibat, yang biasa disebut komponen seferitas. CPP ini memiliki nilai harapan $\left(\psi_{1}(\mathrm{t})\right)$ dan varian $\left(\mathrm{V}_{1}(\mathrm{t})\right)$ seperti pada persamaan (3) dan (4) (Ross, 2019).

$$
\begin{gathered}
\psi_{1}(\mathrm{t})=\mathrm{E}[\mathrm{Y}(\mathrm{t})]=\mathrm{E}[\mathrm{N}(\mathrm{t})] \mathrm{E}\left[\mathrm{X}_{1}\right] \\
\mathrm{V}_{1}(\mathrm{t})=\operatorname{var}[\mathrm{Y}(\mathrm{t})]=\mathrm{E}[\mathrm{N}(\mathrm{t})] \mathrm{E}\left[\mathrm{X}_{1}^{2}\right]
\end{gathered}
$$

Terlihat bahwa nilai harapan dari CPP adalah perkalian antara nilai harapan dari proses HPP dan nilai harapan dari distribusi yang dibawa oleh komponen besaran akibat atau seferitasnya.

Selanjutnya, asumsikan bahwa $X_{i}$ memiliki distribusi gamma dengan parameter skala $\theta>0$ dan parameter bentuk $\alpha>0$. Nilai harapan, varian dan orde ke-2 dari $\mathrm{X}_{\mathrm{i}}$ disajikan pada persamaan (5).

$$
\mathrm{E}[\mathrm{X}]=\frac{\alpha}{\theta}, \operatorname{var}[\mathrm{X}]=\frac{\alpha}{\theta^{2}} \text { dan } \mathrm{E}\left[\mathrm{X}^{2}\right]=\frac{(\alpha+1) \alpha}{\theta^{2}} .
$$

Selanjutnya dengan mensubstitusikan persamaan (1) dan (5) ke persamaan (3) dan (4), maka didapatkan hasil pada persamaan (6) dan (7),

$$
\begin{aligned}
& \psi_{1}(\mathrm{t})=\frac{\alpha \lambda \mathrm{t}}{\theta}, \text { dan } \\
& \mathrm{V}_{1}(\mathrm{t})=\frac{(\alpha+1) \alpha \lambda \mathrm{t}}{\theta^{2}} .
\end{aligned}
$$


Jika parameter pada disribusi gamma di atas diasumsikan dengan $\alpha=1$, maka nilai harapan dan varian dari distribusi tersebut menjadi nilai harapan dan varian pada distribusi eksponensial.

Karena bentuk model CPP yang memilki komponen proses Poisson yang homogen, yaitu memilki fungsi intensitas yang konstan, maka dikembangkan model CPP yang memiliki komponen proses Poisson yang nonhomogen yaitu memiliki fungsi intensitas yang tak homogen. Pengembangan teori ini didasari pada banyaknya kejadian acak yang terjadi pada fenomena nyata yang seringkali memiliki bentuk fungsi intensitas yang tidak selalu konstan.

\section{CPP-NHPP-GD}

Banyaknya kejadian yang terjadi pada waktu $\mathrm{T}$ dapat direpresentasikan oleh proses pencacahan $\left\{\mathrm{N}^{*}(\mathrm{t}), \mathrm{t} \geq 0\right\}$. Jika proses ini berdistribusi Poisson dengan fungsi intensitas $\lambda(t)>0$, maka proses ini dikatakan sebagai proses Poisson nonhomogen (nonhomogeneous Poisson process (NHPP)). Karena memiliki fungsi intensitas yang tak konstan, maka proses ini dapat dikatakan sebagai proses yang bergantung pada waktu. Hal ini dikarenakan ketika diambil beberapa waktu, maka nilai yang didapatkan tidak konstan dan mengikuti tren pada fungsi tersebut. Definisi, nilai harapan, varian dan teorema terkait NHPP dapat dilihat pada Ross (2019).

$$
E\left[N^{*}(t)\right]=\Lambda(t) \text { dan } \operatorname{var}\left[N^{*}(t)\right]=\Lambda(t),
$$

dengan $\Lambda(t)=\int_{0}^{t} \lambda(s)$ ds. Terlihat bahwa nilai harapan dan varian dari NHPP memiliki nilai yang sama. Nilai harapan dan varian pada proses ini didapatkan dari integral dari 0 sampai t dari fungsi intensitas tak homogen yang dibawanya.

Definisi proses Poisson majemuk yang memilki komponen pada proses Poisson-nya berupa proses Poison nonhomogen dimodifikasi menjadi definisi sebagai berikut:

Definisi 2. Suatu proses $\left\{Y^{*}(t), t \geq 0\right\}$ dikatakan sebagai suatu proses Poisson majemuk, jika proses tersebut dapat direpresentasikan sebagai,

$$
Y^{*}(t)=\sum_{i=1}^{N *(t)} X_{i}, t \geq 0
$$


Syarif Abdullah, Sidik Susilo, Miftahul Huda, Nina Valentika, Sri Istiyarti Uswatun Chasanah, Agusyarif Rezka Nuha, Aswata Wisnuadji, Fajri Ikhsan, Yazid Rukmayadi

dengan $\left\{\mathrm{N}^{*}(\mathrm{t}), \mathrm{t} \geq 0\right\}$ adalah suatu proses Poisson nonhomogen dan $\left\{\mathrm{X}_{\mathrm{i}}, \mathrm{i} \geq 1\right\}$ adalah suatu keluarga dari variabel acak i.i.d (independent and identically distributed) yang juga bebas dari proses $\left\{\mathrm{N}^{*}(\mathrm{t}), \mathrm{t} \geq 0\right\}$ (Abdullah, 2017).

Definisi 2 di atas merupakan definisi dari CPP-NHPP. Proses ini berturutturut memiliki nilai harapan $\left(\psi_{2}(\mathrm{t})\right)$ dan varian $\left(\mathrm{V}_{2}(\mathrm{t})\right)$ sebagai berikut (Abdullah, 2017):

$$
\begin{gathered}
\psi_{2}(\mathrm{t})=\mathrm{E}\left[\mathrm{Y}^{*}(\mathrm{t})\right]=\mathrm{E}\left[\mathrm{N}^{*}(\mathrm{t})\right] \mathrm{E}\left[\mathrm{X}_{1}\right] \\
\mathrm{V}_{2}(\mathrm{t})=\operatorname{var}\left[\mathrm{Y}^{*}(\mathrm{t})\right]=\mathrm{E}\left[\mathrm{N}^{*}(\mathrm{t})\right] \mathrm{E}\left[\mathrm{X}_{1}^{2}\right] .
\end{gathered}
$$

Persamaan (8) dan (5) disubstitusikan ke persamaan (10) dan (11), sehingga didapatkan persamaan (12) dan (13).

$$
\begin{gathered}
\psi_{2}(\mathrm{t})=\frac{\alpha \Lambda(\mathrm{t})}{\theta}, \text { dan } \\
\mathrm{V}_{2}(\mathrm{t})=\frac{(\alpha+1) \alpha \Lambda(\mathrm{t})}{\theta^{2}} .
\end{gathered}
$$

Jika parameter pada disribusi gamma di atas diasumsikan dengan $\alpha=1$, maka nilai harapan dan varian dari distribusi tersebut menjadi nilai harapan dan varian pada distribusi eksponensial. Karena proses Poisson majemuk ini bergantung pada waktu maka nilai harapan dan varian ini berupa fungsi, yang berturut-turut disebut sebagai fungsi nilai harapan dan fungsi varian.

\section{Penduga Parameter CPP-NHPP-GD}

Sebelum membuat generalisasi algoritma, dirumuskan terlebih dahulu tentang penduga-penduga parameternya. Pada bagian ini disajikan rumusan untuk penduga parameter pada fungsi nilai harapan dan varian pada CPP-NHPP-GD. Karena parameter-parameter pada persamaan (10) dan (11) tidak diketahui, maka diperlukan rumusan penduga parameter. Persamaan (14) dan (15) merupakan rumusan penduga parameter untuk fungsi nilai harapan dan fungsi varian pada proses ini.

$$
\begin{gathered}
\hat{\psi}_{2}(\mathrm{t})=\hat{\mathrm{E}}\left[\mathrm{Y}^{*}(\mathrm{t})\right]=\hat{\mathrm{E}}\left[\mathrm{N}^{*}(\mathrm{t})\right] \hat{\mathrm{E}}\left[\mathrm{X}_{1}\right] \\
\hat{\mathrm{V}}_{2}(\mathrm{t})=\hat{\operatorname{var}}\left[\mathrm{Y}^{*}(\mathrm{t})\right]=\hat{\mathrm{E}}\left[\mathrm{N}^{*}(\mathrm{t})\right] \hat{\mathrm{E}}\left[\mathrm{X}_{1}^{2}\right] .
\end{gathered}
$$

Karena komponen pada NHPP dan disribusi gamma juga tidak diketahui, maka dari persamaan (14) dan (15) didapatkan rumusan sebagai berikut. 


$$
\begin{gathered}
\hat{\Psi}_{2}(\mathrm{t})=\frac{\hat{\alpha} \hat{\Lambda}(\mathrm{t})}{\hat{\theta}}, \text { dan } \\
\hat{\mathrm{V}}_{2}(\mathrm{t})=\frac{(\hat{\alpha}+1) \hat{\alpha} \hat{\Lambda}(\mathrm{t})}{\hat{\theta}^{2}} .
\end{gathered}
$$

Penduga $\hat{\alpha}$ dan $\hat{\theta}$ berturut-turut adalah penduga parameter bentuk (shape) dan penduga parameter skala (scale) dari distribusi gamma. Sedangkan penduga $\hat{\Lambda}(\mathrm{t})$ adalah penduga parameter dari proses Poisson nonhomogen. Dari rumusan di atas, komponen penduga yang harus dirumuskan adalah $\hat{\alpha}, \hat{\theta}$ dan $\hat{\Lambda}(\mathrm{t})$. Pada bagian rumusan penduga $\hat{\Lambda}(\mathrm{t})$, bergantung pada intensitas yang diduga yaitu dapat berupa fungsi konstan, linear, berpangkat, fungsi siklik atau fungsi yang lain. Agar lebih terlihat perubahannya, maka pada penelitian ini dipilih fungsi sederhana yaitu berupa fungsi linear.

Karena $\Lambda(t)=\int_{0}^{t} \lambda(s)$ ds, maka dengan menggunakan intensitas fungsi linear $\lambda(s)=$ as didapatkan

$$
\hat{\Lambda}(\mathrm{t})=\int_{0}^{\mathrm{t}} \hat{\lambda}(\mathrm{s}) \mathrm{ds}=\frac{\hat{\mathrm{a}}}{2} \mathrm{t}^{2}
$$

Terlihat bahwa pada penduga $\hat{\Lambda}(\mathrm{t})$ memiliki unsur yang tidak diketahui juga, yaitu $\hat{a}$, sehingga pada parameter ini perlu pula untuk dirumuskan parameter penduganya. Dengan menggunakan metode moment, maka penduga untuk parameter untuk â adalah sebagai berikut:

$$
\hat{a}=\frac{2 N([0, n])}{n^{2}} .
$$

Sedangkan penduga untuk parameter dengan distribusi gamma dengan menggunkan metode moment, maka didapatkan rumusan penduga sebagai berikut.

$$
\widehat{\theta}=\frac{\overline{\mathrm{X}}}{\mathrm{X}^{2}-(\overline{\mathrm{X}})^{2}}, \text { dan } \hat{\alpha}=\hat{\theta} \overline{\mathrm{X}}=\frac{(\overline{\mathrm{X}})^{2}}{\overline{\mathrm{X}^{2}}-(\overline{\mathrm{X}})^{2}},
$$

dengan $\bar{X}=\frac{1}{n} \sum_{i=1}^{n} X_{i}$ dan $\overline{X^{2}}=\frac{1}{n} \sum_{i=1}^{n} X_{i}^{2}$.

Dengan mensubtitusikan persamaan (18), (19) dan (20) ke persamaan (16) dan (17), maka didapatkan rumusan penduga-penduga untuk fungsi nilai harapan 
dan varian pada CPP dengan komponen NHPP berupa fungsi linear dan distribusi gamma berturut-turut sebagai berikut.

$$
\begin{aligned}
& \widehat{\psi}_{2}(\mathrm{t})=\frac{\hat{\alpha} \widehat{\Lambda}(\mathrm{t})}{\widehat{\theta}} \\
& =\frac{\frac{(\bar{X})^{2}}{\overline{X^{2}}-(\bar{X})^{2}} \frac{2 N([0, n]) t^{2}}{2 n^{2}}}{\frac{\bar{X}}{\overline{X^{2}}-(\bar{X})^{2}}} \\
& =\frac{\mathrm{N}([0, \mathrm{n}]) \overline{\mathrm{X}}}{\mathrm{n}^{2}} \mathrm{t}^{2}, \text { dan } \\
& \widehat{V}_{2}(t)=\frac{(\hat{\alpha}+1) \hat{\alpha} \widehat{\Lambda}(t)}{\hat{\theta}^{2}}=\frac{(\hat{\alpha}+1)}{\hat{\theta}} \frac{\hat{\alpha} \widehat{\Lambda}(\mathrm{t})}{\hat{\theta}}=\left(\frac{\hat{\alpha}}{\hat{\theta}}+\frac{1}{\hat{\theta}}\right) \frac{\hat{\alpha} \widehat{\Lambda}(\mathrm{t})}{\hat{\theta}} \\
& =\left(\overline{\mathrm{X}}+\frac{\overline{\mathrm{X}^{2}}-(\overline{\mathrm{X}})^{2}}{\overline{\mathrm{X}}}\right) \frac{\mathrm{N}([0, \mathrm{n}]) \overline{\mathrm{X}}}{\mathrm{n}^{2}} \mathrm{t}^{2} \\
& =\left((\bar{X})^{2}+\overline{X^{2}}-(\bar{X})^{2}\right) \frac{N([0, n])}{n^{2}} t^{2} \\
& =\frac{\mathrm{N}([0, \mathrm{n}]) \overline{\mathrm{X}^{2}}}{\mathrm{n}^{2}} \mathrm{t}^{2},
\end{aligned}
$$

dengan $\bar{X}=\frac{1}{n} \sum_{i=1}^{n} X_{i}$ dan $\overline{X^{2}}=\frac{1}{n} \sum_{i=1}^{n} X_{i}^{2}$

\section{Generalisasi Algoritma CPP-NHPP-GD}

Bagian ini dibahas tentang generalisasi algoritma CPP-NHPP-GD. Generalisasi ini merupakan pengembangan algoritma yang telah dilakukan pada Abdullah (2019, 2020a, 2020b) yang diperumum pada komponen besaran akibatnya menjadi bentuk distribusi asumsi berupa distribusi gamma. Generalisasi algoritma pada penelitian ini memiliki 3 langkah utama dalam pembangkitan proses Poison majemuk secara beruntun, yaitu membangkitkan suatu proses Poisson nonhomogen yang memiliki intensitas tak konstan, kemudian membangkitkan suatu bilangan acak $X_{i}$ yang memiliki distribusi gamma, dan selanjutnya menghitung pada bagian compound Poisson process (CPP).

Sebagai gambaran, misalkan pada bidang aktuaria adalah setiap adanya kejadian kecelakaan, maka pemegang polis akan melakukan klaim kepada perusahan asuransi. Di saat pemegang polis tersebut melakukan klaim dan sesuai dengan prosedur yang ada, maka perusahaan akan memberikan suatu besaran 
klaim yang akan diberikan kepada pemegang polis. Proses kejadian yang terjadi kecelakan dan kedatangann polis tersebut ke perusahaan dapat diasumsikan memiliki proses Poisson. Karena kejadian kedatangan ini terjadi secara acak dan kadang terjadi kenaikan atau penurunan pada suatu interval waktu tertentu, maka proses Poisson ini dapat diasumsikan memiliki fungsi intensitas tak konstan, sehingga proses Poisson ini merupakan proses Poisson yang nonhomogen (NHPP). Pada bagian besaran akibat, pada kejadian ini dapat diasumsikan berupa distribusi gamma karena proses tesebut memiliki ciri atau karakteristik yang dimiliki oleh distribusi gamma. Proses kejadian di atas, mulai dari peristiwa yang terjadi hingga dihitung besaran akibatnya, dapat dikategorikan sebagai proses Poisson majemuk karena pada terjadinya suatu kejadian diasumsikan memiliki proses Poisson.

Dari Definisi 2 (Persamaan (9)), misalkan untuk suatu $\omega \in \Omega$, suatu realisasi tunggal $\mathrm{N}(\omega)$ dari $\left\{\mathrm{N}^{*}(\mathrm{t}), \mathrm{t} \geq 0\right\}$ yang terdefinisi pada ruang peluang $(\Omega, F, \mathbf{P})$ diamati pada suatu interval terbatas $[0, n]$. Pada proses ini memiliki fungsi intensitas tak konstan $\lambda(\mathrm{t})$ dan diobservasi pula pada ruang peluangnya. Untuk setiap titik data pada $\mathrm{N}(\omega) \cap[0, \mathrm{n}]$ yang diamati, maka peubah acak $\mathrm{X}_{\mathrm{i}}$ yang bersesuaian juga diamati. $X_{i}$ diasumsikan berupa berdistribusi gamma dengan parameter $\theta\left(X_{i} \sim \operatorname{Gamma}(\alpha, \theta)\right)$. Artinya adalah setiap kali kejadian yang terjadi, maka didapatkan suatu pasangan pada komponen besaran akibat. Dalam membangkitkan NHPP, perlu diperhatikan bahwa harus dipilih nilai $\lambda$ sedemikinan sehingga $\lambda(\mathrm{t}) \leq \lambda$ dengan nilai peluang $\lambda(\mathrm{t}) / \lambda$ untuk semua $\mathrm{t} \leq \mathrm{T}$. Setiap NHPP (disimbolkan dengan $Z_{i}$ ) diobservasi, maka dihasilkan realisasi tunggal $\mathrm{Z}_{\mathrm{i}}$ dan $\mathrm{X}_{\mathrm{i}}$ mulai dibangkitkan dengan diberikan asumsi berupa distribusi gamma. Modifikasi algoritma untuk membangkitkan CPP-NHPP-GD tipe 1 diillustrasikan pada flowchart Gambar 2. 

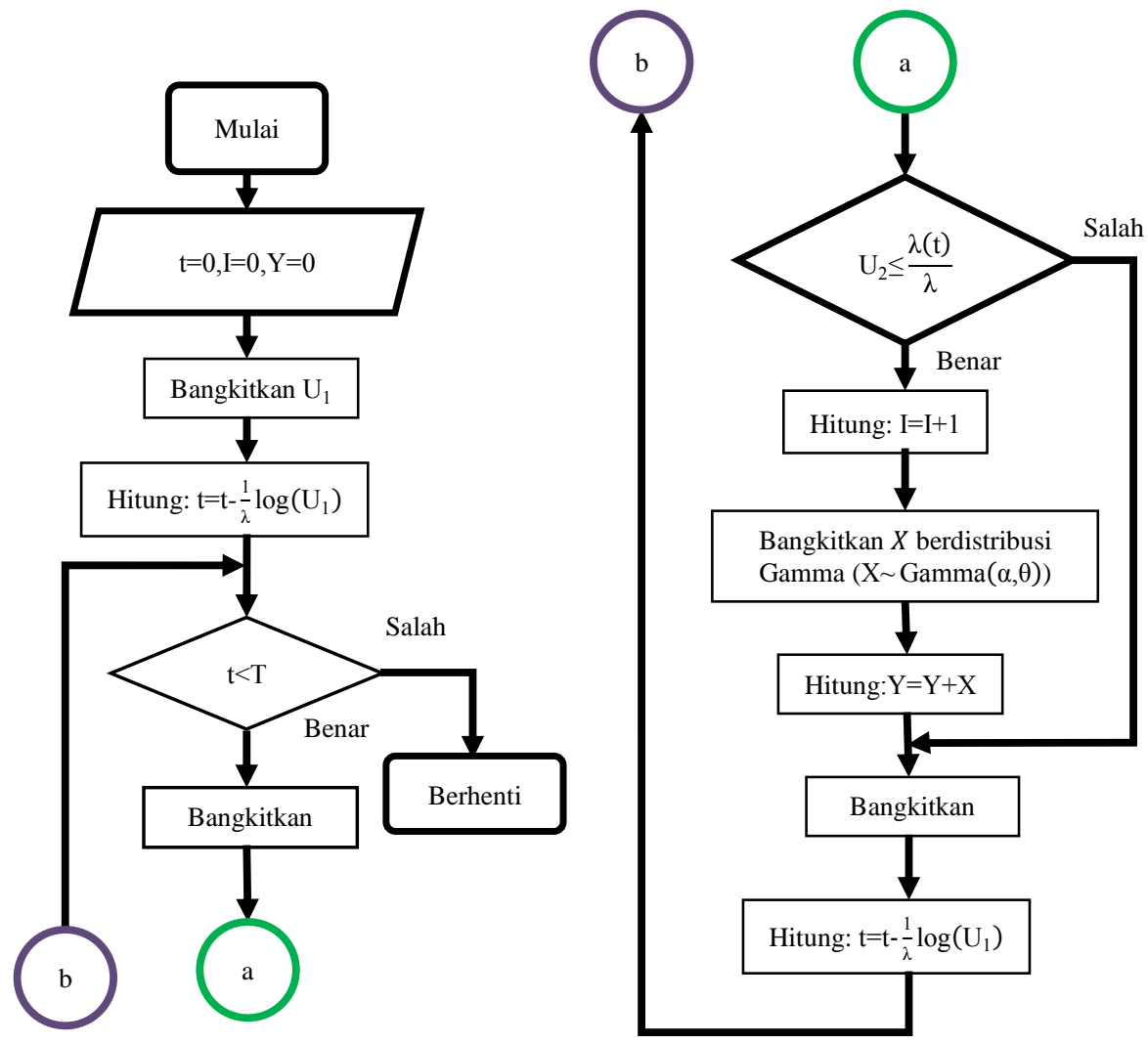

Gambar 2. Flowchart CPP-NHPP-GD Tipe 1.

Langkah-langkah berikut merupakan modifikasi pembuatan algoritma dari CPP NHPP-GD tipe 1 dari flowchat Gambar 2.

Langkah $1: \mathrm{t}=0, \mathrm{I}=0, \mathrm{Y}^{*}=0$.

Langkah 2 : Bangkitkan $\mathrm{U}_{1}$.

Langkah 3 : Hitung $\mathrm{t}=\mathrm{t}-\frac{1}{\lambda} \log \left(\mathrm{U}_{1}\right)$.

Langkah 4 : Jika $\mathrm{t}>\mathrm{T}$, Berhenti.

Langkah 5 : Bangkitkan $\mathrm{U}_{2}$.

Langkah 6 : Jika $\mathrm{U}_{2} \leq \lambda(\mathrm{t}) / \lambda$.

Langkah $7 \quad$ : $\quad$ Hitung $\mathrm{I}=\mathrm{I}+1$.

Langkah $8 \quad: \quad$ Bangkitkan $X(X \sim \operatorname{Gamma}(\alpha, \theta))$.

Langkah 9 : $\quad$ Hitung $\mathrm{Y}^{*}=\mathrm{Y}^{*}+\mathrm{X}$.

Langkah 10 : Ulangi langkah 2.

Adapun maksud dari beberapa simbol pada flowchart dan algoritma di atas sebagai berikut: $\mathrm{Y}^{*}$ merepresentasikan CPP-NHPP-GD, $\mathrm{t}$ adalah waktu, $\mathrm{T}$ 
adalah unit waktu pertama, $\mathrm{U}_{1}$ dan $\mathrm{U}_{2}$ merupakan bilangan acak berdistribusi seragam, I adalah banyaknya kejadian yang terjadi (event that occured) pada waktu $\mathrm{t}, \lambda(\mathrm{t})$ merupakan fungsi intensitas tak konstan dengan syarat $\lambda(\mathrm{t}) \leq \lambda$, dan $\mathrm{X}$ merupakan variabel acak berdistribusi gamma dengan parameter bentuk $\alpha$ dan parameter skala $\theta$.

Pada tipe 1 di atas, interval waktu masih belum dibagi menjadi subinterval, sehingga memungkinkan untuk dilakukan modifikasi kembali dengan membagi interval waktu tersebut menjadi beberapa subinterval. Setelah dibagi menjadi beberapa subinterval, maka dilakukan kembali prosedur atau langkah-langkah pada modifikasi tipe 1. Akibat dari pembagian subinterval ini adalah kejadian yang didapatkan akan menghasilkan kejadian yang terjadi atau muncul yang akan ditolak lebih sedikit ketika $\lambda(\mathrm{t})$ mendekati $\lambda$. Karena interval waktu dibagi menjadi beberapa subinterval, maka fungsi intensitas tersebut juga akan terbagi menjadi berapa fungsi intensitas. Dalam membangkitkan NHPP, dipilih nilai $\lambda_{\mathrm{i}}$ sedemikian sehingga $\lambda(\mathrm{s}) \leq \lambda_{\mathrm{i}}, \quad \forall \mathrm{s} \in\left(\mathrm{t}_{\mathrm{i}-1}, \mathrm{t}_{\mathrm{i}}\right)$ dengan peluang $\lambda(\mathrm{t}) / \lambda_{\mathrm{i}}$. Karena exponensial tidak memiliki memori (Ross 2019), maka bentuk eksponensial selanjutnya dapat digunakan peluang $\lambda_{\mathrm{i}}\left[\mathrm{Z}-\left(\mathrm{t}_{\mathrm{i}}-\mathrm{t}\right)\right] / \lambda_{\mathrm{i}+1}$. Setiapkali $\mathrm{Z}_{\mathrm{i}}$ terjadi, maka menghasilkan suatu realisasi tunggal untuk dapat menghasilkan nilai $X_{i}$ yang berdistribusi gamma. Sehigga $\mathrm{Y}(\mathrm{T})$ akan didapatkan dengan menghitung jumlah dari masing-masing $\mathrm{X}_{\mathrm{i}}$. Adapun langkah-langkah untuk menghasilkan CPP-NHPP-GD tipe 2 diilustrasikan pada flowchart Gambar 3. 
Syarif Abdullah, Sidik Susilo, Miftahul Huda, Nina Valentika, Sri Istiyarti Uswatun Chasanah, Agusyarif Rezka Nuha, Aswata Wisnuadji, Fajri Ikhsan, Yazid Rukmayadi

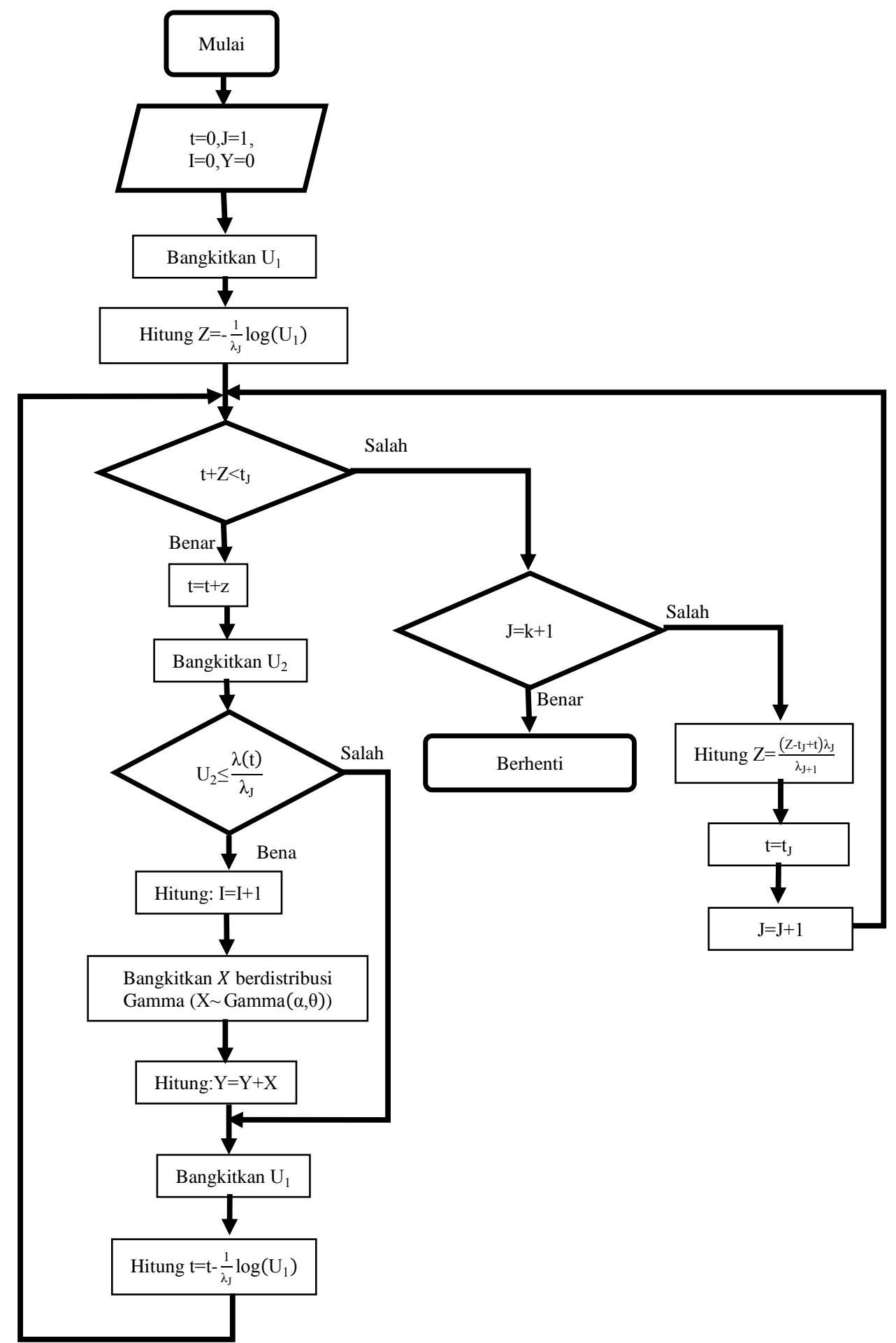

Gambar 3. Flowchart CPP-NHPP-GD Tipe 2

Modifikasi pembuatan algoritma CPP NHPP-GD tipe 2 pada flowchart di atas memiliki langkah-langkah sebagai berikut. 
Langkah $1: \mathrm{t}=0, \mathrm{I}=0, \mathrm{Y}^{*}=0$.

Langkah 2 : Bangkitkan $\mathrm{U}_{1}$.

Langkah 3 : Hitung $Z=-\frac{1}{\lambda} \log \left(U_{1}\right)$.

Langkah 4 : Jika $\mathrm{t}+\mathrm{Z}>\mathrm{t}_{\mathrm{J}}$, pergi ke langkah 12 .

Langkah 5 : Hitung $\mathrm{t}=\mathrm{t}+\mathrm{Z}$.

Langkah 6 : Bangkitkan $\mathrm{U}_{2}$.

Langkah $7 \quad$ Jika $\mathrm{U}_{2} \leq \lambda(\mathrm{t}) / \lambda_{\mathrm{J}}$.

Langkah $8 \quad$ : $\quad$ Hitung $\mathbf{I}=\mathbf{I}+1$.

Langkah $9 \quad$ : $\quad$ Bangkitkan $X(X \sim \operatorname{Gamma}(\alpha, \theta))$.

Langkah $10 \quad$ : $\quad$ Hitung $\mathrm{Y}^{*}=\mathrm{Y}^{*}+\mathrm{X}$.

Langkah 11 : Ulangi langkah 2.

Langkah 12 : Jika $\mathbf{J}=\mathrm{k}+1$, Berhenti.

Langkah 13 : Hitung $\mathrm{Z}=\lambda_{\mathrm{J}}\left[\mathrm{Z}-\left(\mathrm{t}_{\mathrm{J}}-\mathrm{t}\right)\right] / \lambda_{\mathrm{J}+1}$.

Langkah 14 : Hitung $\mathrm{t}=\mathrm{t}_{\mathrm{J}}$.

Langkah 15 : Hitung $\mathbf{J}=\mathbf{J}+1$.

Langkah 16 : Ulangi langkah 4.

Adapun maksud dari simbol-simbol pada flowchart dan algoritma di atas sebagai berikut: $\mathrm{Y}^{*}$ merepresentasikan CPP-NHPP-GD, $\mathrm{t}$ adalah waktu, $\mathrm{T}$ adalah unit waktu pertama, $\mathrm{J}$ adalah interval waktu. $\mathrm{U}_{1}$ dan $\mathrm{U}_{2}$ merupakan variabel acak berdistribusi seragam, I adalah banyaknya kejadian yang terjadi (event that occured) pada waktu $\mathrm{t}, \lambda(\mathrm{t})$ merupakan fungsi intensitas tak konstan dengan syarat $\lambda(\mathrm{t}) \leq \lambda$ yang kemudian di-breakdown menjadi $\lambda(\mathrm{s}) \leq \lambda_{\mathrm{i}}$ untuk setiap $\mathrm{s} \in\left(\mathrm{t}_{\mathrm{i}-1}, \mathrm{t}_{\mathrm{i}}\right)$ dengan peluang $\lambda(\mathrm{t}) / \lambda_{\mathrm{i}}$, dan $\mathrm{X}$ adalah variabel acak berdistribusi gamma dengan parameter bentuk $\alpha$ dan parameter skala $\theta$.

\section{SIMPULAN}

Hasil penelitian ini telah didapatkan model dan rumusan penduga-penduga untuk nilai harapan dan varian pada proses Poisson majemuk dengan komponen banyaknya kejadian berupa proses Poisson nonhomogen dan komponen besaran 
Syarif Abdullah, Sidik Susilo, Miftahul Huda, Nina Valentika, Sri Istiyarti Uswatun Chasanah, Agusyarif Rezka Nuha, Aswata Wisnuadji, Fajri Ikhsan, Yazid Rukmayadi

akibat dengan distribusi gamma. Pada penelitian ini didapatkan pula generalisasi algoritma thinning process pada proses Poisson majemuk tipe 1 dan 2 dengan komponen proses Poisson nonhomogen dan distribusi gamma. Algoritma tipe 1 merupakan hasil modifikasi dan generalisasi algoritma dari model CPP-HPP dengan merubah komponen pada proses Poisson-nya menjadi bentuk nonhomogen dan komponen pada bagian besaran akibat berupa distribusi gamma. Algoritma tipe 2 merupakan hasil modifikasi dari tipe 1 dengan melakukan breakdown interval menjadi subiterval.

\section{UCAPAN TERIMA KASIH}

Artikel ini dipublikasikan atas dukungan skema hibah Penelitian Dosen Pemula (PDP) dari Universitas Sultan Ageng Tirtayasa, Indonesia. Penulis mengucapkan terima kasih kepada reviewer atas kritik dan saran untuk peningkatan kualitas pada artikel ini dan kepada tim redaksi atas perbaikan tampilan artikel ini. Terimakasih pula penulis ucapkan kepada Laboratorium Komputasi: Jurusan Teknik Mesin Universitas Sultan Ageng Tirtayasa, Jurusan Statistika Universitas Bina Bangsa, Jurusan Matematika Universitas Pamulang, Jurusan Matematika UIN Sunan Kalijaga, Jurusan Matematika Universitas Negeri Golontalo, dan Jurusan Metalurgi Universitas Sultan Ageng Tirtayasa, atas kerjasama dan fasilitas yang diberikan sehingga penelitian ini terlaksana.

\section{DAFTAR PUSTAKA}

Abdullah, S., Mangku, I. W., \& Siswadi. (2017). Estimating the variance function of a compound cyclic Poisson process in the presence of linear trend. Far East Journal of Mathematical Sciences,102(3), 559-572. http://dx.doi.org/10.17654/MS102030559.

Abdullah, S., Ikhsan, F., Ula, S., \& Rukmayadi, Y. (2019). Thinning process algorithms for compound Poisson process having nonhomogeneous Poisson process (NHPP) intensity functions. IOP Conf. Ser.: Mater. Sci. Eng., 673 012062. http://dx.doi.org/10.1088/1757-899X/673/1/012062.

Abdullah, S., Susilo, S., Mangku, I. W., Ikhsan, F., Ula, S., \& Rukmayadi, Y. (2020). Algorithm for generating compound Poisson process which has nonhomogeneous Poisson process and exponential distribution components. 1st International Multidisciplinary Conference on Education, Technology, and Engineering (IMCETE 2019), Atlantis Press, 241-246. https://doi.org/10.2991/assehr.k.200303.059. 
Abdullah, S., Susilo, S., Ula, S., Aswata, Valentika, N., \& Chasanah, S. I. U. (2020). Algoritma membangkitkan proses Poisson majemuk dengan komponen proses Poisson nonhomogen fungsi linear dan komponen berdistribusi eksponensial. STATMAT: Jurnal Statistika dan Matematika, 2(1), 81-93. https://doi.org/10.32493/sm.v2i1.4224.

Andrzejczak, K., Młyńczak, M., \& Selech, J. (2018). Poisson-distributed failures in the predicting of the cost of corrective maintenance. Eksploatacja $i$ Niezawodnosc-Maintenance and Reliability, 20(4), 602-609. https://doi.org/10.17531/ein.2018.4.11.

Beichelt, F. (2006). Stochastic Processes in Science, Engineering and Finance. New York (US): Chapman \& Hall/CRC Taylor \& Francis Group.

Cha, J. H. (2013). On a stochastic failure model under random shocks. J. Phys.: Conf. Ser., 410 012108. https://doi.org/10.1088/1742-6596/410/1/012108.

Lewis, P., A., W., \& Shedler, G., S. (1979). Simulation Poisson process by thinning. Naval Postgraduate School Montery [Tesis]. California (US): Calhoun.

Makhmudah, F. I., Mangku, I. W., \& Sumarno, H. (2016). Estimating the variance function of a compound cyclic Poisson process. Far East Journal of Mathematical Sciences, 100(6), 911-922. https://doi.org/10.17654/MS100060911.

Mangku, I. W., Ruhiyat, \& Purnaba, I. G. P. (2013). Statistical properties of an estimator for the mean function of a compound cyclic Poisson process. Far East Journal of Mathematical Sciences, 82(2), 227-237.

Pahlajani, C. D., Poulakakis, I., \& Tanner, H. G. (2014). Networked decision making for Poisson processes with application to nuclear detection. IEEE Transaction on Automatic Control, 59(1), 193-198. https://doi.org/10.1109/TAC.2013.2267399.

Ross, S. M. (2012). Simulation. Ed ke-5. Amsterdam (NL): Academic Pr.

Ross, S. M. (2019). Introduction to probability models. Ed. ke-12. Florida (US): Academic Pr.

Ruhiyat, Mangku, I. W., \& Purnaba, I. G. P. (2013). Consistent estimation of the mean function of a compound cyclic Poisson process. Far East Journal of Mathematical Sciences, 77(2), 183-194.

Sampson, W. W. (2009). Modelling stochastic fibrous materials with mathematica $\AA^{\circledR} \quad$ London (UK): $\quad$ Springer-Verlag. https://doi.org/10.1007/978-1-84800-991-2.

Soltanali, H., Rohani, A., Tabasizadeh, M., Abbaspour-Fard, M. H., \& Parida, A. (2019). Operational reliability evaluation-based maintenance planning for automotive production line. Quality Technology \& Quantitative Management. Taylor and Francis Group, 17(2), 186-202. https://doi.org/10.1080/16843703.2019.1567664.

Wibowo, B. A., Mangku, I. W., \& Siswadi. (2017). Statistical properties of an estimator for the mean function of a compound cyclic Poisson process in the presence of linear trend. Arab Journal of Mathematical Science, 23(2), 173-185. https://doi.org/10.1016/j.ajmsc.2016.08.004. 